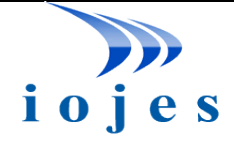

www.iojes.net

\title{
The Effect of Education Status of Parents on Their Parental Attitudes and School Readiness of Their Children*
}

\author{
Research Article \\ Duygu KOZAN , Elvan SAHIN ZETEROGLU² \\ ${ }^{1}$ Uludag University, Faculty of Education, Department of Educational Science, Bursa, Turkey, ORCID: 0000-0001-9560-9553 \\ ${ }^{2}$ Uludag University, Faculty of Education, Department of Educational Science, Bursa, Turkey, ORCID: 0000-0002-2900-7033
}

To cite this article: Kozan, D., \& Sahin-Zeteroglu, E. (2021). The effect of education status of parents on their parental attitudes and school readiness of their children, International Online Journal of Educational Sciences, 13(4), 1046-1068.

\begin{tabular}{ll} 
ARTICLE INFO & ABSTRACT \\
\hline Article History: & $\begin{array}{l}\text { The aim of this study is to determine the effect of the education status of parents of girls and boys } \\
\text { aged between } 48-72 \text { months on the parental attitudes and school readiness of their children who } \\
\text { Received: 23.11.2020 }\end{array}$ \\
attend private preschool education institutions. The study group of the study consists of a total of \\
339 subjects; 113 mothers, 113 fathers and 113 children attending private preschool education \\
institutions in the Bursa province. In this study, Parental Attitude Scale (PTS), which was developed \\
by Karabulut Demir and Sendil and whose validity and reliability analyzes were performed, was \\
used in order to determine parental attitudes. Additionally, the Metropolitan School Readiness Test \\
developed by Hildert et al and adapted into Turkish by Oktay was used to determine the school \\
readiness levels of the children. The data obtained in this study were analyzed with IBM SPSS \\
Statistics Version 22 package program. As a result of the study, it was seen that majority of the parents \\
adopted a democratic attitude. There was a statistically significant relationship between the total \\
readiness status of the children and the educational status of their fathers. The increase in the \\
educational status of the father positively impacted the school readiness of the children. There was a \\
statistically significant difference between the educational status of the fathers in terms of their \\
democratic, permissive and overprotective father scores (p <0.05). It was observed that as the \\
education level of the father increased, the democratic attitude score increased as well and the \\
permissive and overprotective attitude scores, however, decreased. There was statistically no \\
significant difference between the other scores and the educational status (p>0.05).
\end{tabular}

(C) 2021 IOJES. All rights reserved

Keywords:

Preschool education, parental attitude, school readiness, parent education, readiness.

\footnotetext{
* This study was adapted from the master thesis titled "The Relationship Between Parental Attitudes and Children's School Readiness" done at Uludag University in 2020

${ }^{1}$ Corresponding author's address: Uludag University

Telephone: +905532973385

e-mail: dygkzn@gmail.com

DOI: https://doi.org/10.15345/iojes.2021.04.008
} 


\section{Introduction}

"Pre-school education is a systematic education process wherechildren's physical, emotional, linguistic, social and mental development, from birth to compulsory education age, is supported by rich environmental stimulants, where their creative aspects are discovered, and where parents and educators are active, taking into account their developmental characteristics, individual differences and abilities"(Ministry of National Education [MNE], 2016). "The pre-school education program has been developed with the aim of ensuring that children attending pre-school education institutions grow healthily through rich learning experiences, attain the highest level of development in motor, social and emotional, language and cognitive development, acquire self-care skills and be ready for the primary school." (MNE, 2013, p.14). Readiness for primary school is the skill levels that children possess when they start primary school and will affect their success in the following years (Snow, 2006; cited in Adagideli, 2018). There are four main factors that affect the readiness for primary school: These are: Physiological, emotional, mental and environmental factors. Physiological factors are; hearing, vision, hand-eye coordination, health status and gender. The attitude of family members towards each other are amphasized in the emotional factors. Mental factors are generally considered within the scope of intelligence. Environmental factors, on the other hand, include the entire environment of the child, especially the environment in which the child has grown up and the family (Oktay, 2010). Especially during the first five years of a child's life, his/her family and environment are his/her main educational institutions. The natural environment, socio-economic situation of the child, the family's view of education, the number of members in the family affect his/her readiness for primary school (Emig, 2001; cited in Oktay, 2010). It is clearly seen that the most important factor among all these factors is the family. The effect of parental attitude is very important in adapting to school. The economic status and education level of the parents are reflected in both the child's adaptation to school and school success (Demiral, 1996).

Child-rearing mentality and styles are determined by the lifestyle of the host society (Yörükoğlu, 1993). At this point, the attitude differences come to the fore. Even though there are various groupings, the parental attitudes can be examined under four main headings. Three of these are democratic, authoritarian and permissive attitudes defined by Baumrind (1966). Later, in addition to these three dimensions, the overprotective attitude that is common in our culture has been added (Levy, 1966; Kuzgun, 1991; Yavuzer, 1999).

Parents with a democratic attitude are planned and organized. They have high school-readiness expectations, are child-centered, understand their children and help them to solve their problems. They encourage their children to be independent but still set rules and limits for them (Santrock, 2007; cited in Şahin Zeteroğlu, 2014).

Parents with authoritarian attitudes apply pressure on their children, do not take into account the abilities of the child, do not care about their thoughts, want him/her to be fixed-minded, expect obedience, and do not allow verbal communication with the child (Bilal, 1984). This attitude negatively affects the child's relationships with friends and makes it difficult to have an independent personality in the future (Bayraktar, 1998).

Parents with a permissive attitude provide their children with freedom, they cannot control them, and they tolerate to the level of negligence. Children, on the other hand, do whatever they want whenever they want, their impulse control is weak, their academic success is low, and they tolerate themselves (Baumrind, 1966).

Parents with an overly protective attitude, on the other hand, take care, protect and watch over their children more than necessary. Accordingly, they bring limitations to their children in every field, and they make every decision about their children themselves (Demiriz \& Öğretir, 2007). A child brought up with this 
attitude can be a spoiled, self-lacking and timid individual who cannot take any responsibility (Ömeroğlu, 1996).

Considering all this information, it is possible to say that the parental attitudes have an effect on children in every sense. In the present study, it was aimed to make a contribution to the relevant literature by examining the effect of the education-level based attitudes of the parents of young girls and boys aged between 48-72 months and on the school readiness of their children who attend private preschool education institutions.

In line with this general aim, answers to the following questions were sought.

1. Is there a relationship between children's school readiness and education level of their parents?

2. Is there a relationship between parents' attitude scores and their education levels?

\section{Method}

The study was conducted in order to examine and discover the effect of the education status of the parents of girls and boys aged between 48-72 months on the parental attitudes and school readiness of their children who attended private preschool education institutions. For this purpose, the study was carried out in relational scanning model to determine the change and degree of change of many variables. The relational screening model is a research model that aims to determine the existence or degree of change of two or more variables together (Karasar, 2014).

\section{The Study Group}

The target population of the study consisted of children attending private pre-school education institutions in the central district of Bursa province in the 2018-2019 academic year and their parents. The sample of the research was created by criterion sampling. This method is based on situations that meet a set of predetermined criteria. The criteria mentioned can be prepared by the researcher or any existing criteria list may be preferred to be used (Yıldırım \& Şimşek, 2008). The criteria for this study are the age of the children, whether their parents are alive and their volunteering.

\section{Data Collection Tools}

The data of the study were collected by using two different tools. Firstly, the Metropolitan School Readiness Test, developed by Hildert et al. and adapted into Turkish by Oktay, was applied to 113 children attending pre-school education. Parental Attitude Scale (PAS) developed by Karabulut Demir and Şendil was applied to the parents of the participating children. Demographic information of mothers and fathers was obtained with the personal information form. The data obtained in this study were analyzed with IBM SPSS Statistics Version 22 package program.

Fourth level heading. (Body text starts after the heading)

Fifth level heading. (Body text starts after the heading)

\section{Results}

The findings obtained in this part of the study, which has examined the effect of the education status of the parents of 48-72 month-old children attending private kindergartens in the Bursa province, on the parental attitudes and school readiness of their children will be indicated in tables. 
Table 1. The Relationship Between Parental Attitude and Mothers' Education Status

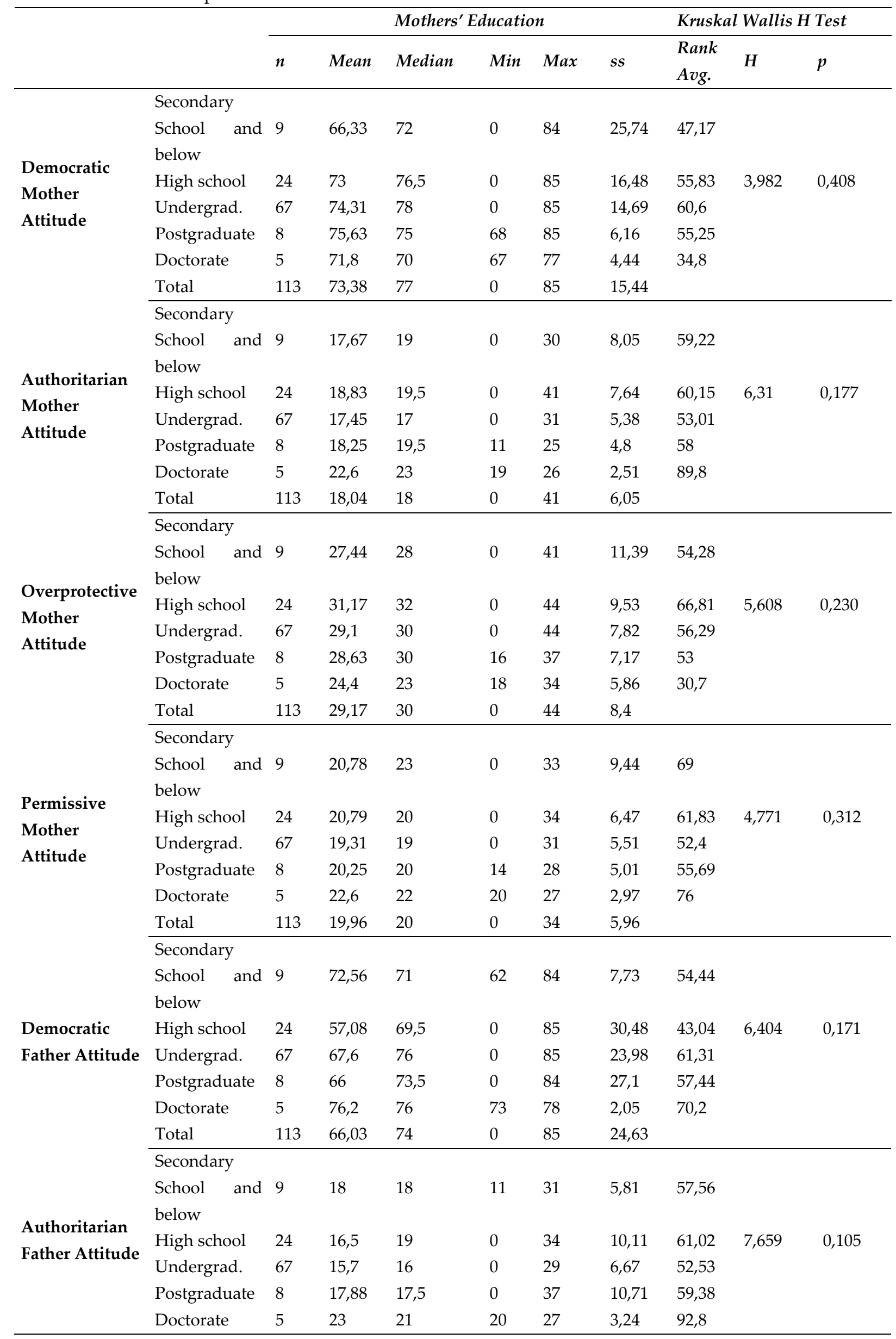




\begin{tabular}{|c|c|c|c|c|c|c|c|c|c|c|}
\hline & Total & 113 & 16,53 & 17 & 0 & 37 & 7,73 & & & \\
\hline & Secondary & & & & & & & & & \\
\hline & $\begin{array}{l}\text { School and } \\
\text { below }\end{array}$ & 9 & 32,67 & 33 & 20 & 42 & 6,86 & 74,44 & & \\
\hline Overprotective & High school & 24 & 25 & 29,5 & 0 & 40 & 14 & 55,65 & 3,869 & 0,424 \\
\hline \multirow[t]{6}{*}{ Father Attitude } & Undergrad. & 67 & 27,04 & 29 & 0 & 42 & 10,62 & 56,55 & & \\
\hline & Postgraduate & 8 & 24,13 & 25,5 & 0 & 36 & 11,1 & 44,13 & & \\
\hline & Doctorate & 5 & 29,6 & 28 & 25 & 34 & 3,78 & 58,7 & & \\
\hline & Total & 113 & 26,96 & 29 & 0 & 42 & 11,07 & & & \\
\hline & Secondary & & & & & & & & & \\
\hline & $\begin{array}{l}\text { School and } \\
\text { below }\end{array}$ & 9 & 24 & 23 & 12 & 35 & 7,4 & 76,11 & & \\
\hline \multirow{5}{*}{$\begin{array}{l}\text { Permissive } \\
\text { Father Attitude }\end{array}$} & High school & 24 & 17,33 & 21 & 0 & 30 & 9,96 & 56,5 & 6,976 & 0,137 \\
\hline & Undergrad. & 67 & 18,36 & 20 & 0 & 28 & 7,33 & 54,54 & & \\
\hline & Postgraduate & 8 & 16,38 & 18 & 0 & 28 & 8,33 & 43,94 & & \\
\hline & Doctorate & 5 & 24 & 23 & 19 & 33 & 5,29 & 78,8 & & \\
\hline & Total & 113 & 18,7 & 21 & 0 & 35 & 8,1 & & & \\
\hline
\end{tabular}

As seen in Table 1, there is no statistically significant difference between mothers' education status in terms of parental attitude scores ( $\mathrm{p}>0.05)$.

Table 2. The Relationship between Parental Attitude and Fathers' Education Status

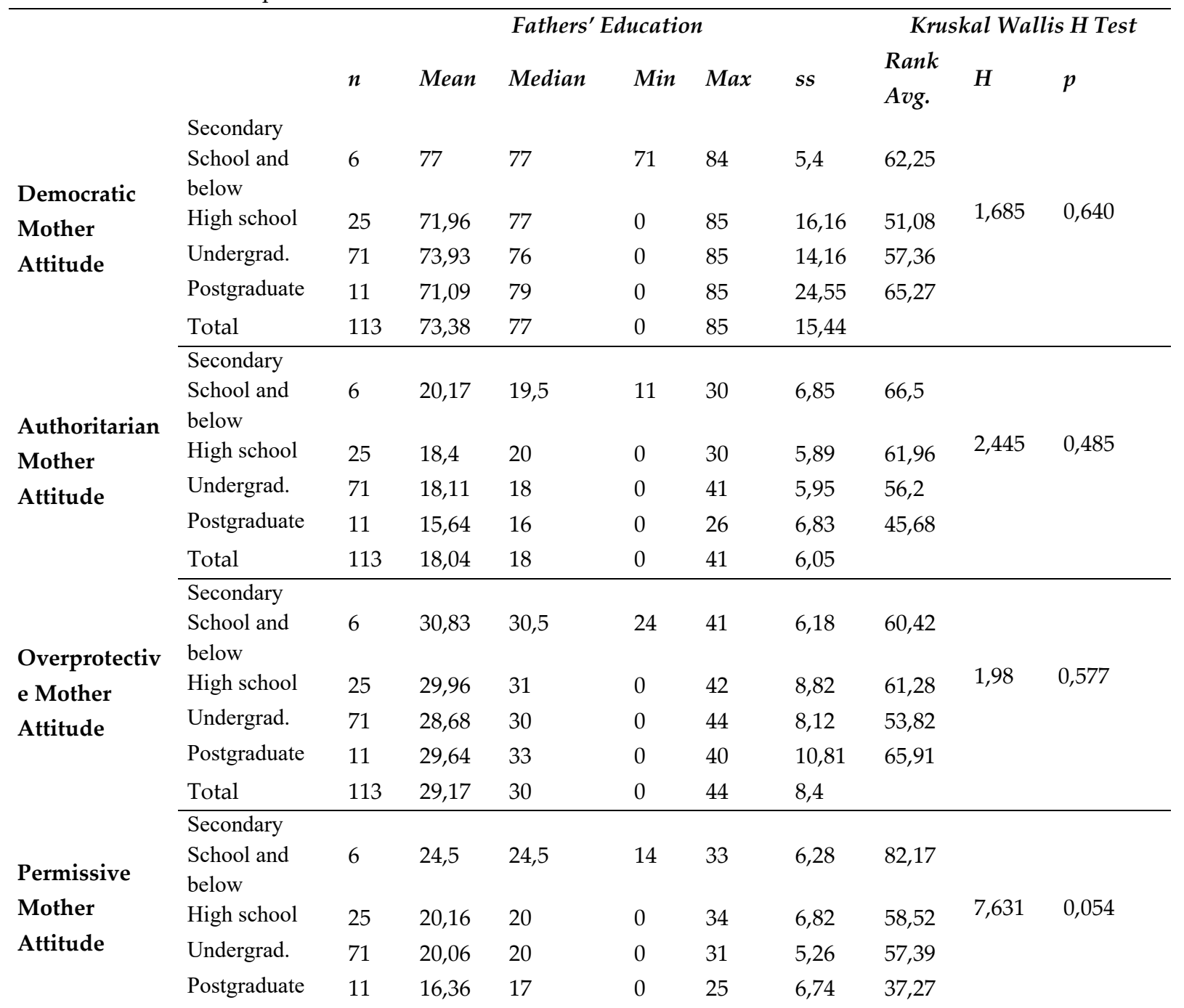




\begin{tabular}{|c|c|c|c|c|c|c|c|c|c|c|}
\hline \multirow{4}{*}{ Democratic } & Total & 113 & 19,96 & 20 & 0 & 34 & 5,96 & & & \\
\hline & Secondary & & & & & & & & \multirow{7}{*}{8,181} & \multirow{7}{*}{0,042} \\
\hline & School and & 6 & 72,33 & 72 & 65 & 82 & 6,19 & 51,67 & & \\
\hline & below & & & & & & & & & \\
\hline Father & High school & 25 & 69,48 & 72 & 0 & 83 & 15,51 & 50,84 & & \\
\hline \multirow{5}{*}{ Attitude } & Undergrad. & 71 & 62,31 & 75 & 0 & 85 & 28,88 & 55,58 & & \\
\hline & Postgraduate & 11 & 78,73 & 79 & 70 & 85 & 5,35 & 83,09 & & \\
\hline & Total & 113 & 66,03 & 74 & 0 & 85 & 24,63 & $2-4$ & & \\
\hline & Secondary & & & & & & & & \multirow{6}{*}{5,686} & \multirow{6}{*}{0,128} \\
\hline & $\begin{array}{l}\text { School and } \\
\text { below }\end{array}$ & 6 & 18,83 & 17 & 11 & 31 & 6,94 & 61,17 & & \\
\hline \multirow{6}{*}{$\begin{array}{l}\text { Authoritarian } \\
\text { Father Attitude }\end{array}$} & High school & 25 & 19,52 & 20 & 0 & 34 & 6,83 & 69,94 & & \\
\hline & Undergrad. & 71 & 14,96 & 16 & 0 & 27 & 7,83 & 51,99 & & \\
\hline & Postgraduate & 11 & 18,64 & 15 & 12 & 37 & 7,5 & 57,64 & & \\
\hline & Total & 113 & 16,53 & 17 & 0 & 37 & 7,73 & & & \\
\hline & Secondary & & & & & & & & \multirow{6}{*}{13,229} & \multirow{6}{*}{0,004} \\
\hline & $\begin{array}{l}\text { School and } \\
\text { below }\end{array}$ & 6 & 35,67 & 34,5 & 29 & 42 & 5,05 & 88,92 & & \\
\hline \multirow{6}{*}{$\begin{array}{l}\text { Overprotective } \\
\text { Father Attitude }\end{array}$} & High school & 25 & 30,64 & 32 & 0 & 39 & 7,76 & 69,3 & & \\
\hline & Undergrad. & 71 & 24,49 & 27 & 0 & 42 & 12,33 & 49,4 & & \\
\hline & Postgraduate & 11 & 29,82 & 29 & 22 & 36 & 4,58 & 60,68 & & \\
\hline & Total & 113 & 26,96 & 29 & 0 & 42 & 11,07 & $3-1$ & & \\
\hline & Secondary & & & & & & & & \multirow{6}{*}{9,382} & \multirow{6}{*}{0,025} \\
\hline & $\begin{array}{l}\text { School and } \\
\text { below }\end{array}$ & 6 & 27,33 & 26,5 & 22 & 35 & 5,39 & 95,08 & & \\
\hline \multirow{4}{*}{$\begin{array}{l}\text { Permissive } \\
\text { Father Attitude }\end{array}$} & High school & 25 & 19,76 & 21 & 0 & 30 & 6,15 & 58,22 & & \\
\hline & Undergrad. & 71 & 17,32 & 20 & 0 & 33 & 8,81 & 52,92 & & \\
\hline & Postgraduate & 11 & 20,45 & 19 & 12 & 28 & 4,7 & 59,77 & & \\
\hline & Total & 113 & 18,7 & 21 & 0 & 35 & 8,1 & $3-1$ & & \\
\hline
\end{tabular}

As seen in Table 2, there is a statistically significant difference between the education level of the fathers in terms of democratic father scores $(p<0.05)$. The democratic attitude score of high school graduate fathers is significantly lower than those with a graduate degree.

There is a statistically significant difference between the educational status of the fathers in terms of overprotective father scores $(\mathrm{p}<0.05)$. Overprotective attitude score of fathers with undergraduate degrees is significantly lower than those with secondary school degree and below.

There is a statistically significant difference between the educational status of the fathers in terms of permissive father scores $(\mathrm{p}<0.05)$. The permissive father score of the undergraduate graduate fathers is significantly lower than those with secondary school degree and below.

There is no statistically significant difference between the education level of the fathers in terms of other parental attitude scores $(\mathrm{p}>0.05)$. 
Tablo 3. Chi-Square Test Results Examining Education of Mothers and Fathers and Children's School Readiness Variable

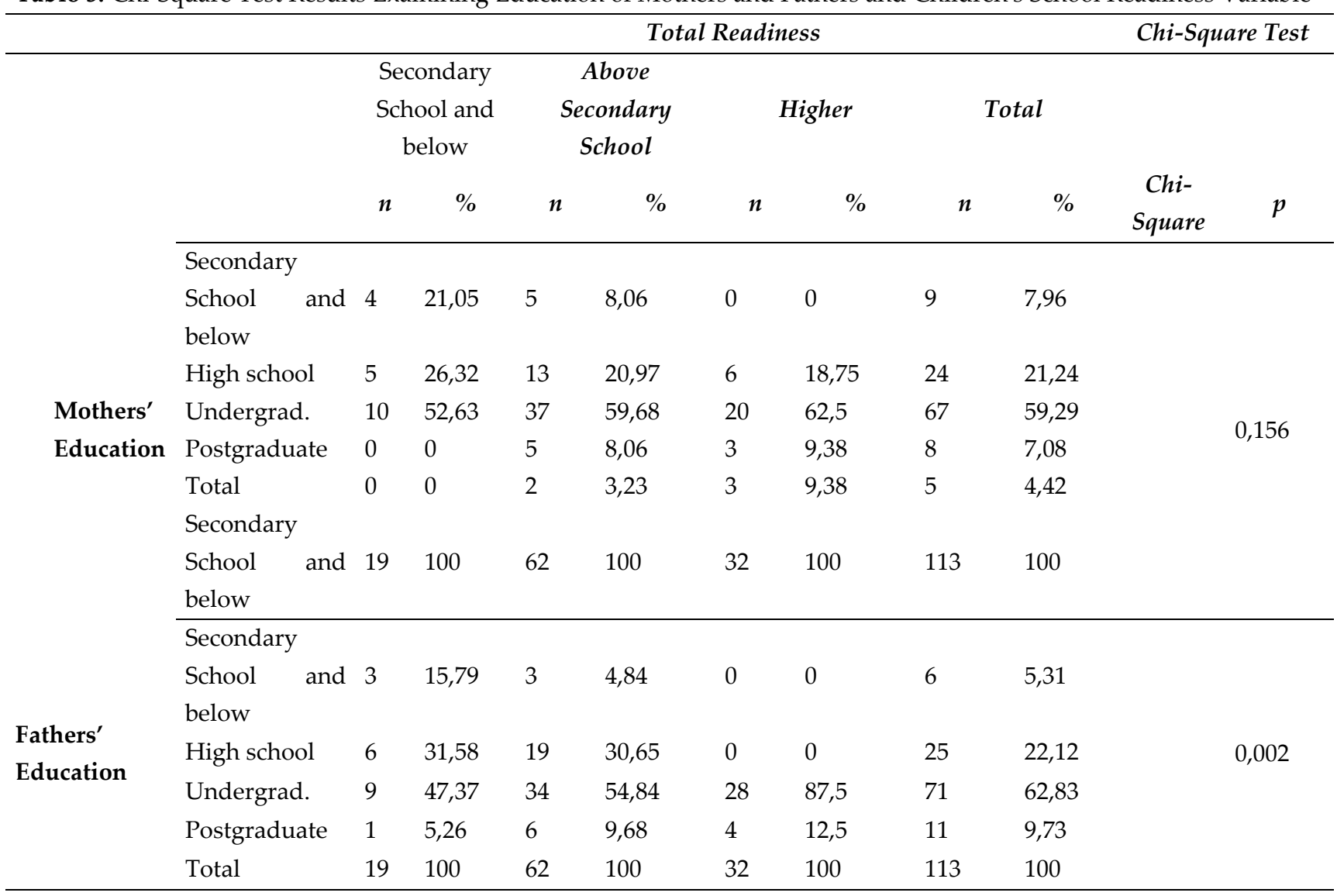

According to Table 3, there is a statistically significant relationship between the total readiness status of the children and the educational status of their fathers $(p<0.05)$.

While the fathers of $47.37 \%$ of the children whose total readiness is intermediate and below the intermediate level, $54.84 \%$ of those whose total readiness is above intermediate and $87.5 \%$ of those whose total readiness is higher have undergraduate degrees, the fathers of $15.79 \%$ of children whose total readiness is intermediate and below the intermediate level, and $4.84 \%$ of those whose total readiness is intermediate level are only secondary school graduates and below. There is no statistically significant relationship between the total readiness of the children and other variables $(\mathrm{p}>0.05)$.

\section{Discussion and Conclusion}

Pre-school period is the time period in which the foundation of one's personality is laid (Kaya, 1997). During this period, the parental attitudes impact the child's cognitive, physical, linguistic, social and emotional development (Razon, 1987). In this study, the effect of education levels of mothers and fathers of children who attended pre-school education on parental attitudes and school readiness of children was examined. In the light of the results obtained from the study and these results, recommendations for teachers and researchers were offered.

Öndegider (2013) stated that the psychological health of the child depended on how s/he understood and interpreted his/her parents' behavior. McElmeel and Sharron (2002) also emphasized the importance of the family in education of values with the statement that "The most effective way of good character for children is for the parents to be a role-model for their children in the best and correct way".

There is no statistically significant difference between mothers' education level in terms of the parental attitude scores. However, there is a statistically significant difference between the democratic attitude score of 
the fathers and the educational status of the fathers in terms of the parental attitude scores $(p<0.05)$. The democratic attitude score of high school graduate fathers is significantly lower than the democratic attitude scores of their fathers who are undergraduates. The overprotective attitude score of fathers with a gradute degree is significantly lower than the overprotective attitude score of fathers who are graduates of secondary school and below. It is clearly observed that as the educational level of fathers increases, they have a more democratic attitude, and their overprotective and permissive attitudes are inversely related to their educational status. There is no statistically significant difference between the educational status of the father in terms of authoritarian father attitude scores ( $p>0.05$ ). By the same token, Begde (2015) stated that fathers' democratic and overprotective attitudes towards their children were affected by the educational status of fathers, and fathers who were primary and secondary school graduates displayed more protective attitudes towards their children compared to fathers with a graduate degree. These results show that the increase in the educational status of fathers reflects positively on their attitudes; they approach their children more democratically, and their overprotective attitudes decrease.

There is a statistically significant relationship between the total readiness status of the children and the educational status of their fathers $(\mathrm{p}<0.05)$. The fathers of $47.37 \%$ of children whose total readiness is intermediate and below the intermediate level, $54.84 \%$ of children with a total readiness above intermediate and $87.5 \%$ of children with higher readiness have undergraduate degrees. The fathers of $15.79 \%$ of children whose total readiness is intermediate and below intermediate level, and $4.84 \%$ of those whose total readiness is above intermediate are secondary school graduates and below. This result shows that as the father's education level increases, the school readiness level of the children also increases. In this case, it is possible to think that the higher the education level of fathers, the more time they spend with their children, the more they support them in this field and the more they cooperate with their children's schooling.

While there was no statistically significant relationship between the total readiness level of the children and the education level of their mothers in this study, in the study conducted by Wynn (2002), the contribution of children's families or caretakers to the development of children's literacy and numeracy skills was evaluated. Wynn concluded that the skills that families considered necessary for school readiness varied according to their education levels and that children of families with higher education completed the preschool period with a wider range of skills. Özcan (2014) and Çıkrıkçı (1999) reported that as the education level of parents increased, child success increased as well. The difference of the present study from the mentioned studies is that the study group has consisted of children attending a private institution and their parents. It is thought that the reason for the lack of a meaningful relationship between the mothers' education level and the children's total readiness level may be due to the fact that the institution allows the families into the world of their children'seducation and family participation activities, and that the differences in maternal education levels can be eliminated in this way.

Seminars can be conducted for the parents of children attending the pre-school education institutions in cooperation with the National Education Directorates and school administration and family participation activities can be organized. The seminars to be organized can provide information to parents about what to expect from their children in the preparation process for primary school and how they can help their children for school readiness. Efforts can be exerted for these seminars to be offered to large masses.

Parents can be offered education opportunities to be informed about parental attitudes. Training programs can be arranged for parents to participate together. This will imply that parents' positive attitude development is supported.

It is thought that the findings obtained within the scope of this study can contribute to the studies to be carried out in the future. Consequently, it is predicted that applying the variables of this study to a larger 
sample will yield more generalizable results. Future researchers who will work on a similar subject can investigate the relationship between different demographic data and the variables available in this study.

In conclusion, the studies that are planned to be conducted in a similar way can be tested using children from different regions, sample groups and different measurement tools.

\section{REFERENCES}

Adagideli, F. H., (2018). Okul öncesi çocuklarının ilkokula hazır bulunuşluklarının yordayıcısı olarak özdüzenleme becerilerinin incelenmesi (Yayınlanmamış Doktora Tezi). Marmara Üniversitesi, İstanbul.

Baumrind, D. (1966). Effects of authoritative parental control on child behavior. Child Development, 37(4), 887907.

Bayraktar, R. (1998). Demokratik tutumun önemi, Okul ve Aile Dergisi, 6(1): 41-43.

Begde, Z. (2015). Öğretmen ve ebeveyn tutumlarının okul öncesi dönem çocuklarının problem çözme becerilerine etkisinin incelenmesi (Yayınlanmamış Yüksek Lisans Tezi). Karabük Üniversitesi, Karabük.

Bilal, G. (1984). Demokratik ve Otoriter Olarak Algılanan Ana-Baba Tutumlarının Çocukların Uyum Düzeyine Etkisi. (Yayınlanmamış Doktora Tezi). Hacettepe Üniversitesi, Ankara.

Çıkrıkçı, S. (1999). Ankara ili merkezindeki resmi banka anaokullarına devam eden 5-6 yaş çocuklarının okul olgunluğu ile aile tutumu arasındaki ilişkinin incelenmesi (Yayınlanmamış Yüksek Lisans Tezi). Gazi Üniversitesi, Ankara.

Demiral, Ö. (1996). Çосй̆un eğitimi. Aile araştırma kurumu bizim dünyamız dizisi. Ankara Başbaşanlık Basımevi. $45-46$.

Demiriz, S. \& Öğretir, A. D. (2007). Alt ve üst sosyo-ekonomik düzeydeki 10 yaş çocuklarının anne tutumlarının incelenmesi. Kastamonu Eğitim Dergisi, 15(1), 105- 122.

Karasar, N. (2014). Bilimsel Araştırma Yöntemi. (27. Baskı). Ankara: Nobel Yayın Dağıtım.

Kaya, M. (1997). Ailede anne baba tutumlarının çocuğun kişilik ve benlik gelişimindeki rolü. O.M.Ü. İlahiyat Fakültesi Dergisi, 9, 193-204.

Kuzgun, Y. (1991). Ana baba tutumlarının bireyin kendini gerçekleştirme düzeyine etkisi. Aile yazıları, Ankara:Başbakanlık Aile Araştırma Kurumu Yayınları.

Levy, D. (1966). Maternal overprotection. New York: The Norton Library, W. W. Norton and Company Inc.

Mceller, L. Sharron. (2002). Character Education: A Book Guide for Teachers, Librarians and Parents. Printed in The United States of America.

MEB (2013). Okul öncesi eğitimi program. Ankara.

MEB (2016). Okul öncesi eğitim programı. Ankara.

Oktay, A. (2010). İlköğretime hazır oluş ve hazır oluşu etkileyen temel faktörler. İlköğgretime hazırlık ve ilköğretim programları. Ankara: Pegem Akademi, 21-34.

Ömeroğlu, F. (1996). Okulöncesi Dönemde Çocuğun Terbiyesinde Annenin Rolü ve Annelerin Çocuk Yetiştirme Tutumları. (Yayınlanmamış Doktora Tezi). Marmara Üniversitesi, İstanbul.

Öndegider, N. (2013). Anne Baba ile Okul Öncesi Çocuk Arasındaki İlişki. Current Approaches in Psychiatry, $5(4), 420-440$. 
Özcan, E. (2014). Birinci sını öğrencilerinin bilişsel okul olgunluğu düzeylerinin okuma yazmayı öğrenme sürecine olan etkisi (Yayınlanmamış Yüksek Lisans Tezi). Eskişehir Osmangazi Üniversitesi, Eskişehir.

Razon, N. (1987). Çocuğun dünyasında oyuncağın yeri ve önemi. Pembe Bağcık Dergisi, 2, 7.

Şahin Zeteroğlu, E. (2014). Altı yaşındaki çocukların anne baba tutumları ile çoklu zekâ alanları ve grup içi etkinlik düzeyleri arasındaki ilişkin (Yayınlanmamış Doktora Tezi). Uludağ Üniversitesi, Bursa.

Wynn, L. (2002). School readiness: Starting your child off right. Wake Forest, NC: North. Carolina Partnership for Children.

Yavuzer, H. (1999). Çocuk Psikolojisi. İstanbul: Remzi Kitabevi.

Yıldırım, A. \& Şimşek, H. (2008). Sosyal Bilimlerde Nitel Araştırma Yöntemleri (6. Baskı). Ankara: Seçkin Yayıncilik.

Yörükoğlu, A. (1993). Çocuk Ruh Sağhlğı. İstanbul: Özgür Yayıncılık. 